\title{
Stunting Management Monitoring System
}

\author{
Helmi Roichatul Jannah ${ }^{1}$, Sri Kusumadewi ${ }^{2}$, Raden Edi Fitriyanto ${ }^{3}$ \\ ${ }^{1,2,3}$ Universitas Islam Indonesia, Yogyakarta \\ 17917209@students.uii.ac.id, 2 94523010@uii.ac.id, ${ }^{3017110417 @ u i i . a c . i d}$
}

\begin{abstract}
Submitted : 13 Januari 2022 | Accepted : Jan 17, 2020 | Published : Jan 20, 2022
Abstract: Stunting is one of the chronic nutritional problems in which the length or height of children is shorter than normal children their age. In the short term, stunting can interfere with brain and physical development, while in the long term, stunting can reduce a person's cognitive abilities and intelligence, as well as being susceptible to various diseases. Stunting cannot be cured, but it can be optimized for growth and development during the 1000 first days (first day of life) by routinely carrying out examinations. This is the goal of this study, namely to build a system that can monitor the health of pregnant women and toddlers aged 0-24 months in an effort to optimize the growth and development of stunting children. Stunting management monitoring system is carried out based on certain nutritional status management which indicates the birth of a child experiencing stunting. The system is built in the form of a website, where expert rules related to the management of nutritional status are translated into the system using the Rule Based Reasoning method. To measure the success of the system, usability testing or functional testing by users is carried out with the attributes of testing the ease of use of the system and the ease of the system to learn. Overall, the Stunting management monitoring system can accommodate the early stages of health monitoring in 1000 first days, however, development will continue in line with user needs.
\end{abstract}

Keywords - stunting, nutrition, first 1000 days of life, monitoring system, rule based reasoning

\section{INTRODUCTION}

Stunting or dwarfing is an impaired growth and development that children experience due to poor nutrition, especially during their First 1000 Days of Life. According to WHO, the condition of stunting in children can be measured based on their length or height, which in this case is not more than -2 SD (standard deviation) from the normal height for their ages. (World Health Organization, 2014) Stunting is the indicator of children's well being as well as the accurate reflection of the brain and intelligence gap, the decreased of the cognitive ability and learning achievement. (Kementerian Kesehatan RI, 2018) In 2017, the government released a program called National Food and Nutrition Action Plan, which focuses on nutrition specific intervention and nutrition sensitive in the children's First 1000 Days of Life up to 6 years old. (Kementerian Desa Pembangunan Daerah Tertinggal dan Transmigrasi, 2017) In 2018, the Indonesian Ministry of Home Affairs, the Indonesian Ministry of National Development Planning, and the Indonesian National Team for the Acceleration of Poverty Reduction released National Strategy of P2K (Stunting). There are five pillars in this strategy. One of them is monitoring and evaluating in order to ensure the quality of the service, increase the accountability and accelerated learning as well as give effective and efficient behavior change campaign and communication to the target groups. (Kementrian Dalam Negeri, Kementerian PPN/Bappenas, 2018)

In the developing countries, there are many factors of stunting, which are lack of exclusive breastfeeding, social economy, low birth weight (LBW), preterm birth, parents' low education attainment and infectious diseases. (Budiastutik \& Rahfiludin, 2019) Other researches also mention that the knowledge on the nutritions and the risks related to stunting the parents have is still low so it can be one of the factors of the stunting in children. (Asweros Umbu Zogara, 2020) In order to elevate the mothers' knowledge and to prevent the stunting in children, it is developed an Android based application called Mobile Health to monitor and evaluate the nutritional status of the children, in which the application can be used by both of the health workers and the parents. Later on, the children's nutritional status can be used to decide the stunting status in children. The nutritional status can be discovered through this application, but for the evaluation can only be done if the patients come to the healthcare services or

*name of corresponding author 
Integrated Services Post (Posyandu) for further and accurate information. (Hendryani, 2020) The systems of recording and reporting the nutritional status in stunting children are developed in other researches, in which the health workers operate the system in managing the data of the children's nutritional status as well as identifying if there is an early problem in the children during the examination. In this system, parents cannot see or monitor the results of the recordings done by the health workers. (Susanti et al., 2019) Other than recording and monitoring systems, some other researches also have already developed stunting detection system; one of them is using Forward Channing method to diagnose stunting. This system is claimed to have $91 \%$ of accuracy made based on the website. The administrators and parents can use the system, but it is not explained clearly the method used to determine the stunting status or not in children. (Farid Wajidi, 2021) An early stunting detection system with a web-base Certainty Factor method is developed in other researches to help the parents measuring the children's nutritional status. The parents can only do the measurement with the results supervised by the health workers. (Afiyan Nur Chafidin, Agung Triayudi, 2021)

Based on the previous researches and development system related to stunting, the big concern is that nutritional status is an important factor to determine whether children experience stunting or not. In Indonesia, in order to decide the children's nutritional status is by reffering to the anthropometic standard released by the Indonesian Ministry of Health. Then, based on National Strategy to Accelerate Stunting Reduction, the optimalization through nutrition specific priotity intervention for breastfeeding mothers and children can be done by promoting and breastfeeding counceling, infant and young child feeding, supplementary food for underweight children, malnutrition management, and growth monitoring promotion. (Kementrian Dalam Negeri, Kementerian PPN/Bappenas, 2018)

\section{LITERATURE REVIEW}

\section{Stunting}

Stunting or dwarfing is a chronic nutritional problem experienced by children under five years old (toddler), especially during their First 1000 Days of Life, which means from fetuses up to 23-year-old babies. According to WHO, a child is categorized as stunting if her/his length or height is not more than -2 SD (standard deviation) from the normal height for her/his age. Generally, children with stunting will have problems with their cognitive and motoric developments, which will affect their productivity when they are older. Besides, children wih stunting are prone to many diseases. (Kementerian Kesehatan RI, 2018)

\section{Management}

Stunting is a chronic nutritional problem experienced by children. Therefore, the children's nutritional status will affect the actions in preventing or optimizing the children's growths. The measurement of maternal mid-upper arm circumference (MUAC) for pregnant mothers is used to screen the chronic energy deficiency (CED). CED in pregnant mothers results them to deliver low birth weight infants, which will increase the risk of stunting in infants. (Thamaria, 2017)

Based on the interview with the nutritionist, dr. Raden Edi Fitriyanto, M. Gizi. the management of preventing stunting is done based on the children's nutritional status. In Indonesia, the nutritional status is regulated by the Indonesian Ministry of Health in the Indonesian Minister of Health Regulation No. 2 of 2020 in the category and the threshold for children's nutritional status as follows. (PERATURAN MENTERI KESEHATAN REPUBLIK INDONESIA NOMOR 82 TAHUN 2013 TENTANG SISTEM INFORMASI MANAJEMEN RUMAH SAKIT, 2014)

\begin{tabular}{|c|l|l|}
\hline \multicolumn{1}{|c|}{ Index } & \multicolumn{1}{|c|}{ Nutritional Status Category } & \multicolumn{1}{c|}{ Threshold (Z-Score) } \\
\hline \multirow{4}{*}{$\begin{array}{c}\text { Children's Weight for Age 0-60 } \\
\text { months }\end{array}$} & Severely underweight & $<-3$ SD \\
\cline { 2 - 3 } & Underweight & -3 SD sd <-2 SD \\
\cline { 2 - 3 } & Normal weight & -2 SD sd +1 SD \\
\cline { 2 - 3 } & Possible risk of overweight1 & $>+1$ SD \\
\hline \multirow{4}{*}{$\begin{array}{c}\text { Children's Length or Height for Age } \\
0-60 \text { months }\end{array}$} & Severely stunted & $<-3$ SD \\
\cline { 2 - 3 } & Stunted & -3 SD sd <-2 SD \\
\cline { 2 - 3 } & Normal & -2 SD sd +3 SD \\
\cline { 2 - 3 } & Tall & $>+3$ SD \\
\hline
\end{tabular}

*name of corresponding author 


\begin{tabular}{|c|c|c|}
\hline \multirow{6}{*}{$\begin{array}{c}\text { Children's Weight Based on the } \\
\text { Length or Height for Age } 0-60 \\
\text { months }\end{array}$} & Severely wasted & $<-3 \mathrm{SD}$ \\
\hline & Wasted & $-3 \mathrm{SD}$ sd $<-2 \mathrm{SD}$ \\
\hline & Normal & $-2 \mathrm{SD} s d+1 \mathrm{SD}$ \\
\hline & Possible risk of overweight & $>+1$ SD sd 2 SD \\
\hline & Overweight & $>+2$ SD sd +3 SD \\
\hline & Obese & $>+3 \mathrm{SD}$ \\
\hline \multirow{6}{*}{$\begin{array}{c}\text { Children's Body Mass Index for } \\
\text { Age 0-60 months }\end{array}$} & Severely wasted $^{3}$ & $<-3 \mathrm{SD}$ \\
\hline & Wasted $^{3}$ & $-3 \mathrm{SD}$ sd $<-2 \mathrm{SD}$ \\
\hline & Normal & $-2 \mathrm{SD} s d+1 \mathrm{SD}$ \\
\hline & Possible risk of overweight & $>+2 \mathrm{SD}$ sd $+3 \mathrm{SD}$ \\
\hline & Overweight & $+2 \mathrm{SD} s d+3 \mathrm{SD}$ \\
\hline & Obese & $>+3 \mathrm{SD}$ \\
\hline \multirow{5}{*}{$\begin{array}{c}\text { Children's Body Mass Index for } \\
\text { Age 5-18 years }\end{array}$} & Severely thinness & $<-3 \mathrm{SD}$ \\
\hline & Thinness & $-3 \mathrm{SD}$ sd $<-2 \mathrm{SD}$ \\
\hline & Normal & $-2 \mathrm{SD} s d+1 \mathrm{SD}$ \\
\hline & Overweight & $+1 \mathrm{SD} s d+2 \mathrm{SD}$ \\
\hline & Obese & $>+2$ SD sd +3 SD \\
\hline
\end{tabular}

Table 2. 1 Category and Threshold for Children's Nutritional Status

Table2.1 is the list of the categories and the threshold for the children's nutritional status, which is body weight index for age, length or height for age, weight based on length or height for age, body mass index for age. However, for the determination of stunting in children is done by examining the weight based on length or height for age depending on the criteria whereas body weight index for age and weight based on length or height reflect their nutritional status.

\section{Rule Based Reasoning}

Rule based reasoning (RBS) is a way to codify the problem solving from the experts so that it is easily understood by the computers. RBS has two inference motors, namely Forward Chaining, in which the reasoning is started from the facts to test the validity of the hypothesis. Meanwhile, Backward Chaining is begun from the hypothesis, which later on the validity is being tested through the knowledge-based facts. (Chowdhary, 2020)

\section{METHOD}

\section{Data Collection}

The data collection is done through three methods, namely observation, interview, and literature review. The observation is done by observing and gathering the data in Community Health Center (Puskesmas) Ngemplak I Yogyakarta, in the nutrition unit and maternal and child health unit. The interview is done with dr. Raden Edi Fitriyanto, M. Gizi., a nutritionist doctor, midwife, and a nutritionist in Community Health Center (Puskesmas) Ngemplak I Yogyakarta. Meanwhile, the literature review is conducted by looking for references with some keywords such as stunting, nutritional status, pregnancy, and rule based reasoning in both books and online sources like Google Scholar, Science Direct as well as credible organization/institute official sites.

\section{System Overview}

The picture below is the general overview of the monitoring system for the management of stunting.

*name of corresponding author 


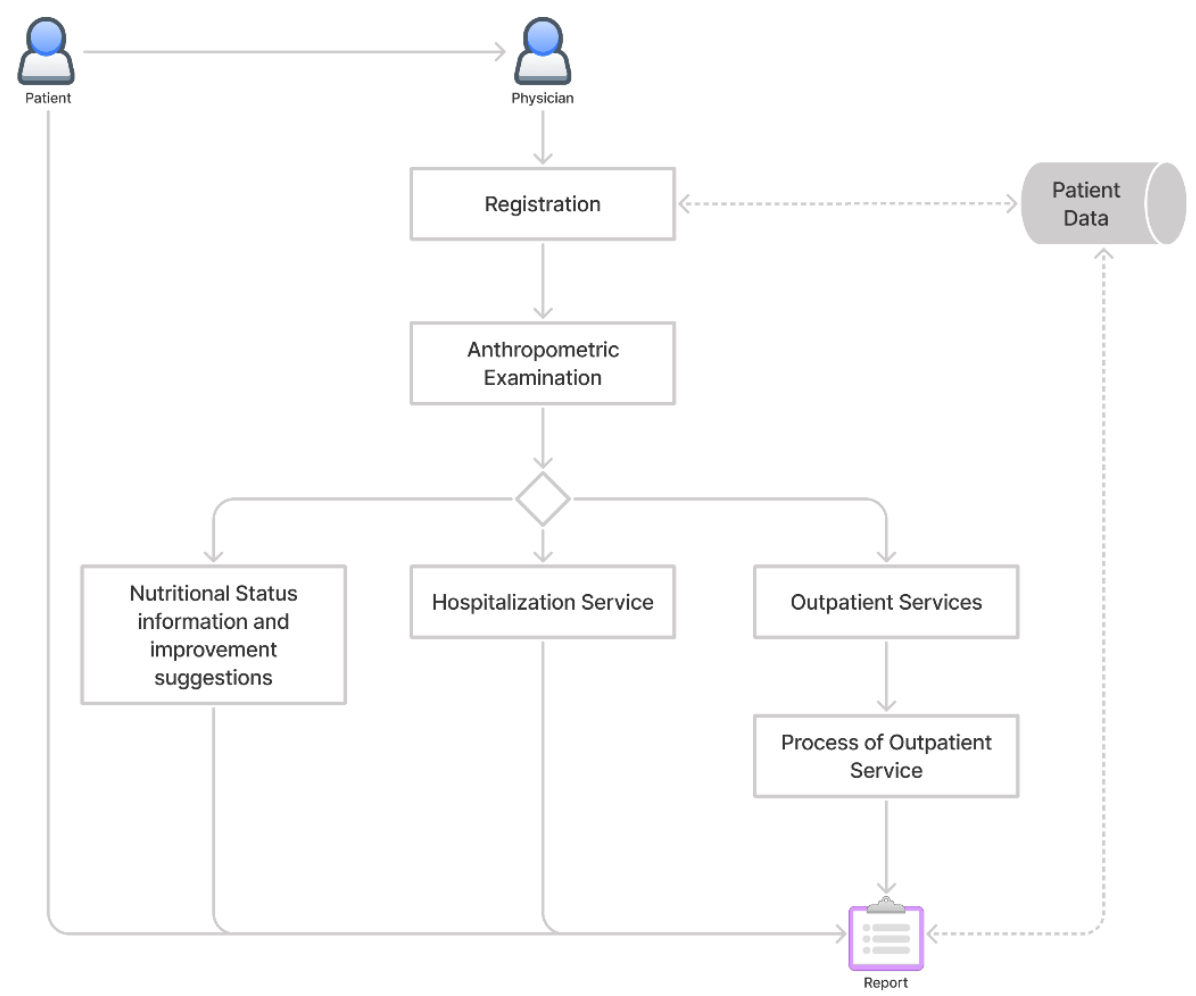

Picture 3. 1 Overview System

Picture 3.1 displays the overview of the flow of the system, in which there are two users involved including the patients and health workers. The patients are pregnant mothers or the parents of the children aged 024 months. Meanwhile, the health workers include the health workers of the Integrated Services Post (Posyandu), midwives or doctors who check up the patients. According to the flow, after the patients register through the health workers who will conduct the test and record the results into the system, the system will provide the results of the input data processing and recommend the suitable services. There are three service recommendations, namely information on nutritional status and suggestions for improvement, inpatient services, and outpatient services. In outpatient service recommendation, the patients will receive the schedule for the next examination as needed. For pregnant mothers, the service given is based on the maternal and child health handbook and the insights from the experts. Meanwhile, for the children, the management is based on the management of malnutrition book.

\section{Forward Chaining}

This research applies Forward Chaining as the method. In determining the children's nutritional status, it is started by doing the early testing to gather the facts or signs, which indicate the occurrence of stunting or are at risk of stunting. The followings are the signs that are collected from the experts. (Kesehatan et al., 2011)

\begin{tabular}{|c|l|}
\hline Code & \multicolumn{1}{|c|}{ Signs } \\
\hline A & There is edema \\
\hline B & Too weak to suckle \\
\hline C & Failure to thrive \\
\hline D & Signs of medical compplications \\
\hline E & Malnutrition \\
\hline
\end{tabular}

Table 3.1 The signs of Nutritional Status in children aged $<6$ months

Table 3.1 is the list of the symptoms or signs in children aged $<6$ months experiencing malnutrition with one or more signs.

*name of corresponding author 


\begin{tabular}{|c|l|}
\hline No & \multicolumn{1}{|c|}{ Rules } \\
\hline R1 & $\begin{array}{l}\text { IF there is edema and too weak to suckle and failure to thrive and there } \\
\text { are signs of complications THEN Malnutrition }\end{array}$ \\
\hline R2 & $\begin{array}{l}\text { IF there is edema and too weak to suckle and failure to thrive THEN } \\
\text { Malnutrition }\end{array}$ \\
\hline R3 & $\begin{array}{l}\text { IF there is edema and failure to thriven and there are signs of } \\
\text { complications THEN Malnutrition }\end{array}$ \\
\hline R4 & $\begin{array}{l}\text { IF there is edema and too weak to suckle and there are signs of } \\
\text { complications THEN Malnutrition }\end{array}$ \\
\hline R5 & $\begin{array}{l}\text { IF too weak to suckle and failure to thrive and there are signs of } \\
\text { complications THEN Malnutrition }\end{array}$ \\
\hline R6 & $\begin{array}{l}\text { IF there is edema and too weak to suckle and failure to thrive and there } \\
\text { are signs of complications THEN Malnutrition }\end{array}$ \\
\hline R7 & $\begin{array}{l}\text { IF there is edema and too weak to suckle and failure to thrive and there } \\
\text { are signs of complications THEN Malnutrition }\end{array}$ \\
\hline R8 & $\begin{array}{l}\text { IF there is edema and too weak to suckle and failure to thriveand there } \\
\text { are signs of complications THEN Malnutrition }\end{array}$ \\
\hline R9 & $\begin{array}{l}\text { IF there is edema and too weak to suckle and failure to thriven and there } \\
\text { are signs of complications THEN Malnutrition }\end{array}$ \\
\hline R10 & $\begin{array}{l}\text { IF there is edema and too weak to suckle and failure to thriven and there } \\
\text { are signs of complications THEN Malnutrition }\end{array}$ \\
\hline
\end{tabular}

Table 3.2 The basic rules of the Nutritional Status in children aged $<6$ months

Table 3.2 presents some of the rules to determine the nutritional status that allows a combination of one or more signs that indicate children are stunted.

\begin{tabular}{|c|l|}
\hline Code & \multicolumn{1}{|c|}{ Sings } \\
\hline A & Underweight \\
\hline B & Edema in the whole body $(+3$ edema $)$ \\
\hline C & Minimum edema in both back of the hands/feet $(+1$ or +2 edema $)$ \\
\hline D & MUAC $<11,5$ \\
\hline E & MUAC $<11,5-12,5$ \\
\hline F & Anorexia \\
\hline G & Severe Dehydration \\
\hline H & Lethargy or decreased consciousness \\
\hline I & High fever \\
\hline J & Severe pneumonia \\
\hline K & Severe anemia \\
\hline L & Malnutrition with complications \\
\hline M & Malnutrition without complications \\
\hline N & Malnutrition \\
\hline
\end{tabular}

Table 3.3 The signs of the Nutritional Status in children aged 6-24 months

Table 3.3 is the lists of the signs or symptoms of children aged 6-24 months experiencing complications of malnutrition, malnutrition without medical complications and malnutrition with one or more signs mentioned above.

*name of corresponding author 


\begin{tabular}{|c|c|}
\hline No & Rules \\
\hline $\mathrm{R} 1$ & $\begin{array}{l}\text { IF underweight and edema in the whole body }(+3 \text { edema) and MUAC }<11,5 \text { and anorexia and severe } \\
\text { dehydration and lethargy or decreased consciousness and high fever and severe pneumonia and severe } \\
\text { anemia THEN Malnutrition with Complications }\end{array}$ \\
\hline R2 & $\begin{array}{l}\text { IF underweight and edema in the whole body ( }+3 \text { edema) and MUAC }<11,5 \text { and anorexia THEN } \\
\text { Malnutrition with Complications }\end{array}$ \\
\hline R3 & $\begin{array}{l}\text { IF underweight and edema in the whole body ( }+3 \text { edema) and } M U A C<11,5 \text { and severe dehydration } \\
\text { THEN Malnutrition with Complications }\end{array}$ \\
\hline R4 & $\begin{array}{l}\text { IF underweight and edema in the whole body }(+3 \text { edema) and MUAC }<11,5 \text { and lethargy or decreased } \\
\text { consciousness THEN Malnutrition with Complications }\end{array}$ \\
\hline R5 & $\begin{array}{l}\text { IF underweight and edema in the whole body ( }+3 \text { edema) and MUAC }<11,5 \text { and high fever THEN } \\
\text { Malnutrition with Complications }\end{array}$ \\
\hline R6 & $\begin{array}{l}\text { IF underweight and edema in the whole body ( }+3 \text { edema) and } \mathrm{MUAC}<11,5 \text { and severe pneumonia } \\
\text { THEN Malnutrition with Complications }\end{array}$ \\
\hline R7 & $\begin{array}{l}\text { IF underweight and edema in the whole body ( }+3 \text { edema) and MUAC }<11,5 \text { and severe anemia THEN } \\
\text { Malnutrition with Complications }\end{array}$ \\
\hline R8 & $\begin{array}{l}\text { IF underweight and edema in the whole body }(+3 \text { edema) and MUAC }<11,5 \text { and anorexia and severe } \\
\text { dehydration and lethargy or decreased consciousness and high fever and severe pneumonia THEN } \\
\text { Malnutrition with Complications }\end{array}$ \\
\hline R9 & $\begin{array}{l}\text { IF underweight and edema in the whole body ( }+3 \text { edema) and MUAC }<11,5 \text { and anorexia and lethargy } \\
\text { or decreased consciousness and high fever and severe pneumonia and severe anemia THEN } \\
\text { Malnutrition with Complications }\end{array}$ \\
\hline R10 & $\begin{array}{l}\text { IF underweight and edema in the whole body ( }+3 \text { edema) and MUAC }<11,5 \text { and anorexia and severe } \\
\text { dehydration and lethargy or decreased consciousness and high fever and severe anemia THEN } \\
\text { Malnutrition with Complications }\end{array}$ \\
\hline
\end{tabular}

Table 3.4 Basic rules of Nutritional Status in children aged 6-24 months

Table 3.4 is the list of several rules to determine the nutritional status in children aged 6-24 months. The rule is developed based on the guidebook for managing malnutrition that is adjusted to the signs in the patients or children.

\section{RESULTS}

\section{Implementation Results}

Based on the implementation results of the literature review and data analysis, the system is developed into a website-based application with a system interface designed according to the users' needs. The following is the screenshots of the system that has been made. 


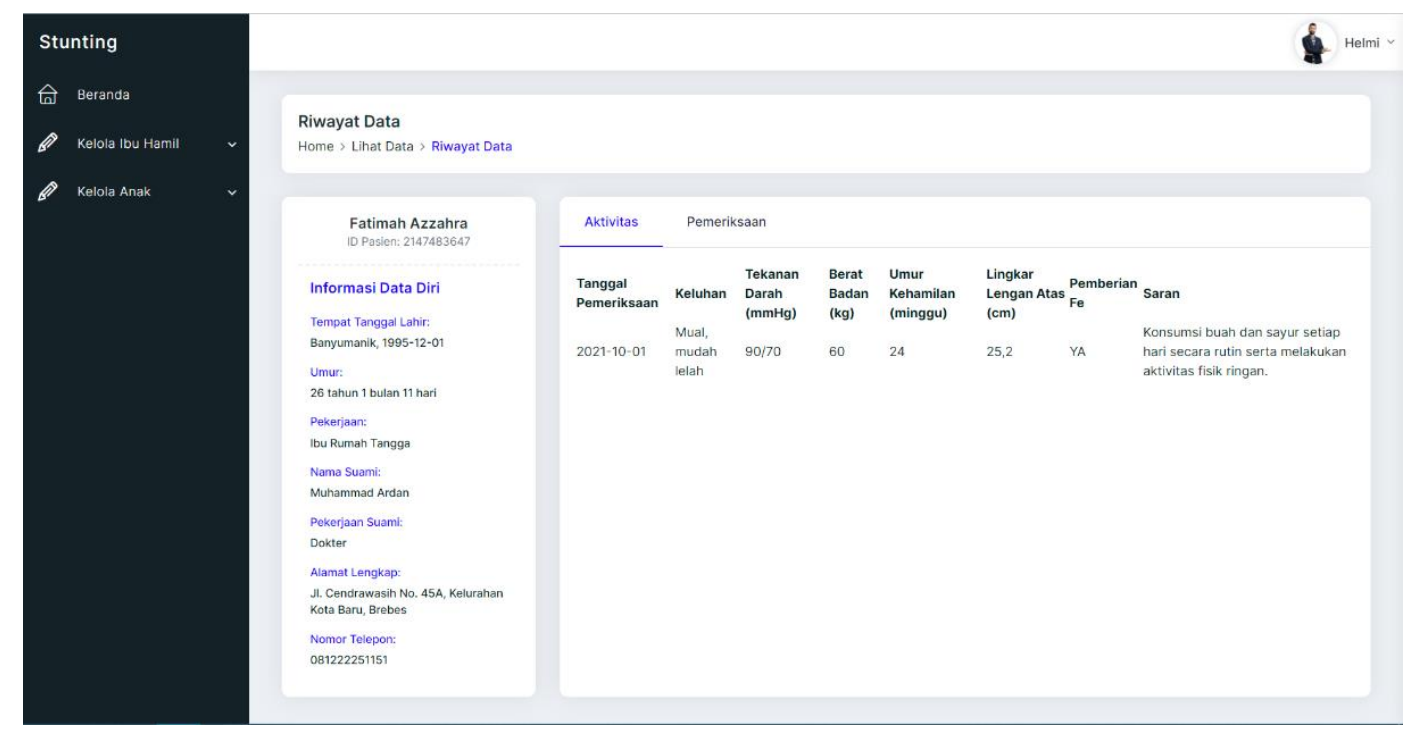

Picture 4. 1 Testing result page interface for pregnant mothers

Picture 4.2 shows the testing result for the pregnant mothers done by the health workers. The data presented are the testing date, complaints, blood pressure, weight, gestational age, mid upper arm circumference, giving the $\mathrm{Fe}$ and suggestions to improve or uplift the maternal nutritional status during pregnancy.

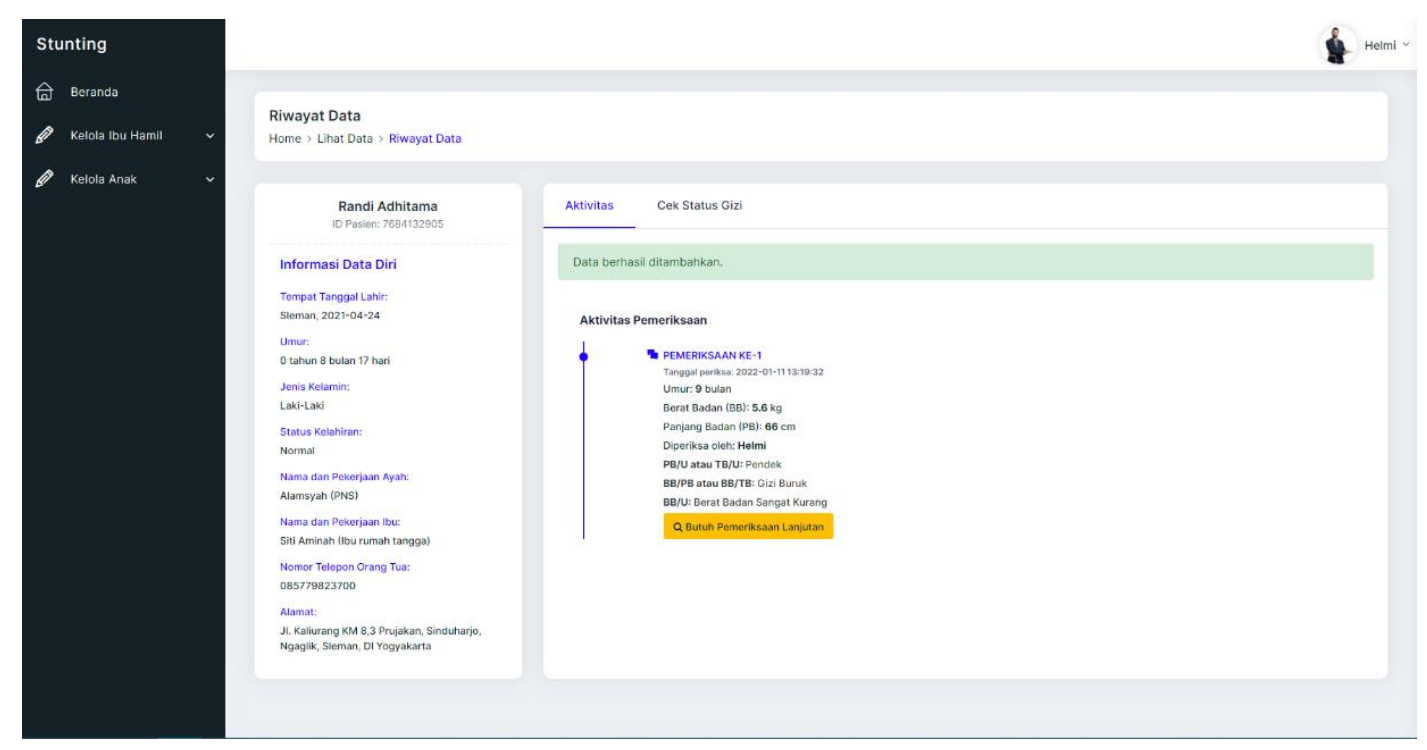

Picture 4. 2 Testing interface of the children's nutritional status

Picture 4.3 presents the testing result of the children's nutritional status, in which the health workers will enter the weight and length or height of the children during the testing. The system will perform the children's nutritional status based on the result of the test. If the children are considered as malnourished, then the system will direct them to the follow-up examination. However, if the nutritional status is normal, the health workers will only give the suggestions to intensify or maintain the children's nutritional status. 

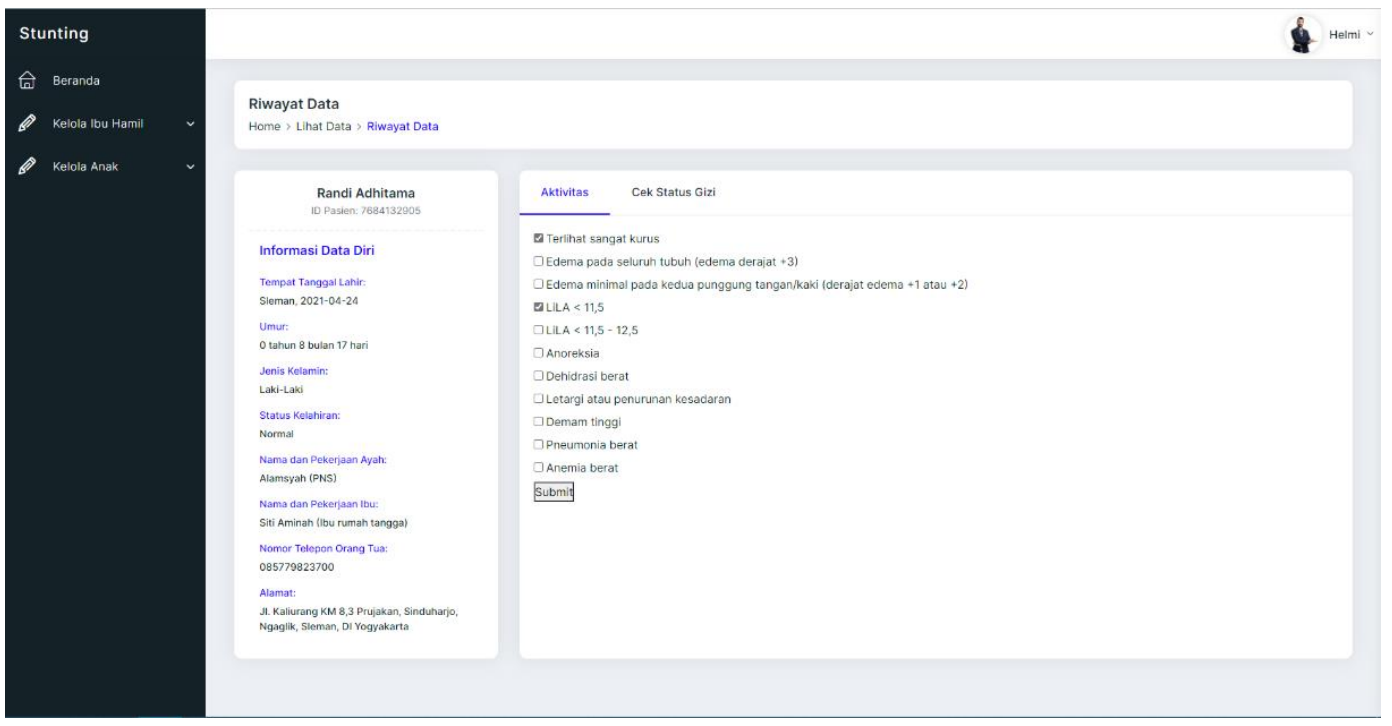

Picture 4. 3 Advanced testing interface on malnutrition status

Picture 4.3 shows the advanced testing, in which the health workers will record the physical signs or symptoms in malnourished children.

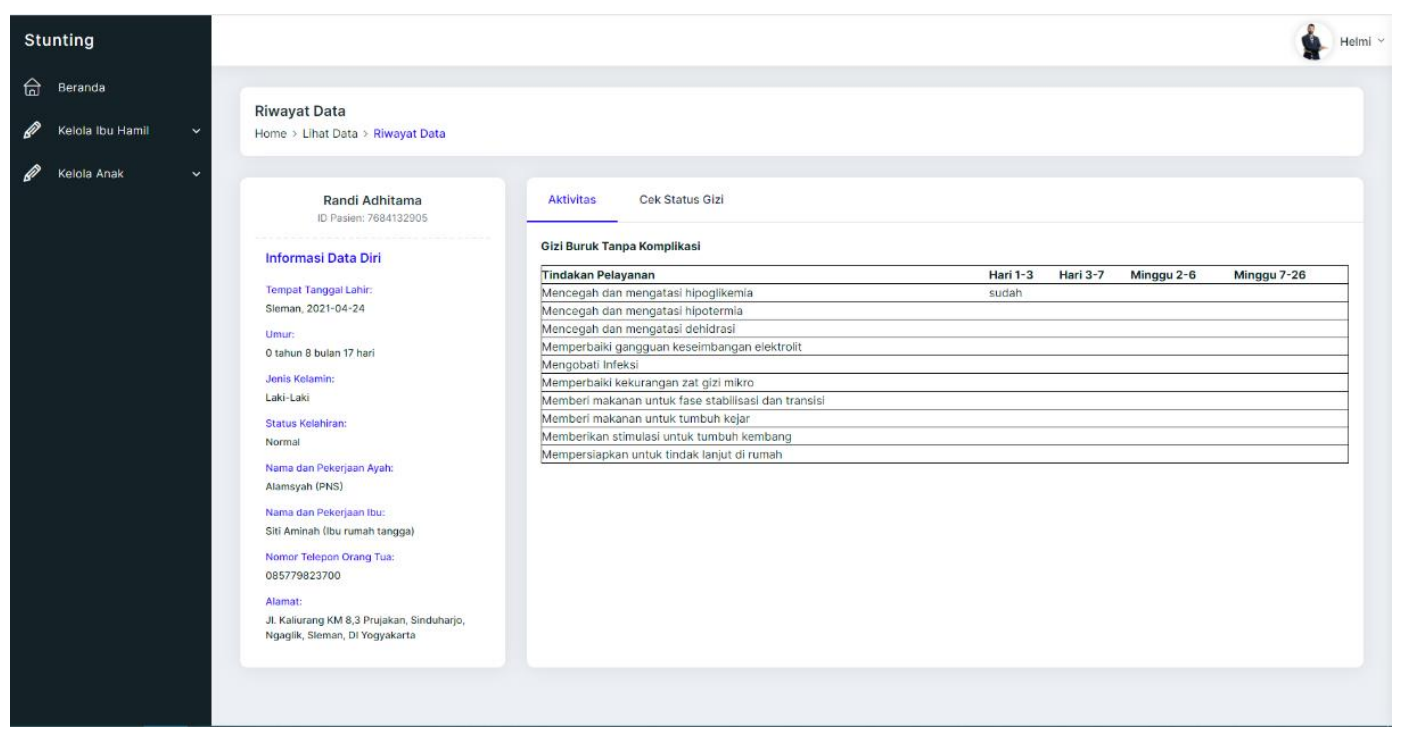

Picture 4. 4 Management interface based on nutritional status and treatment schedule 


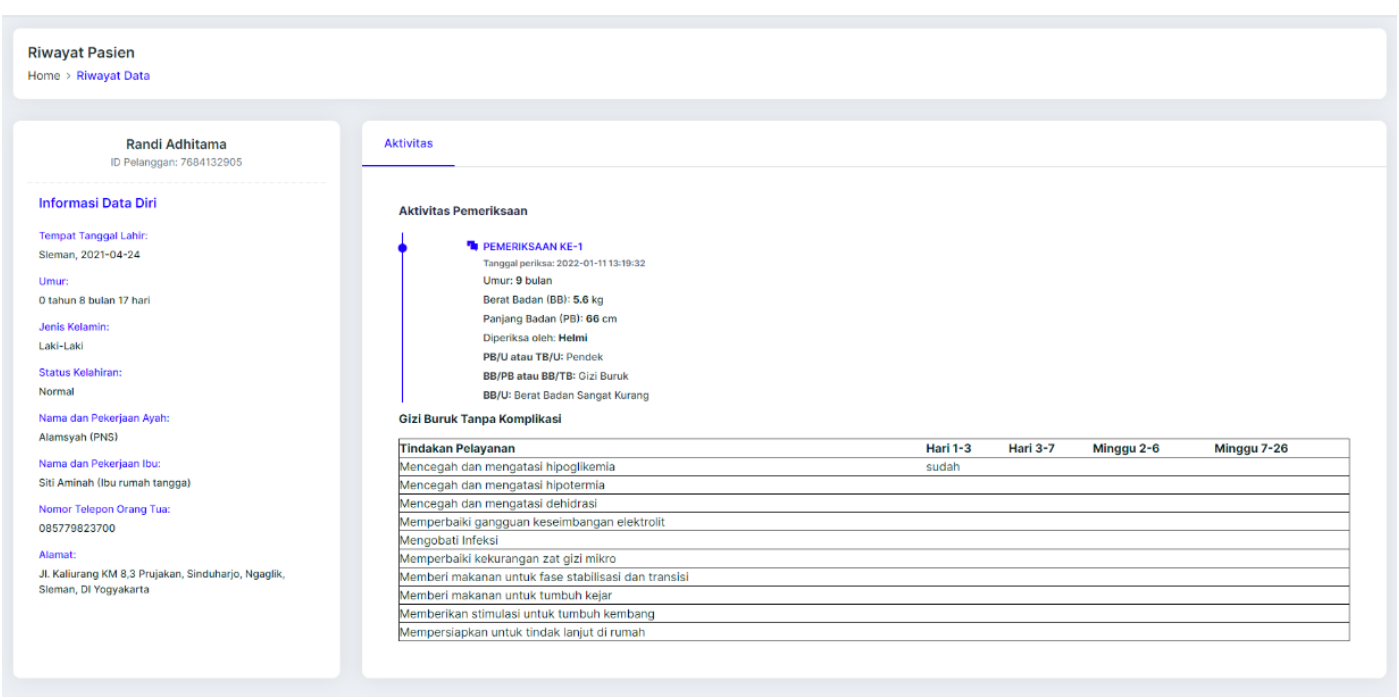

Picture 4. 5 Testing result interface for parents

\subsection{Testing}

\subsubsection{Validity Testing}

The validity testing is used to test the validity of the system in determining the children's nutritional status. The testing is done based on the data gathered from Community Health Center (Puskesmas) Ngemplak 1 Sleman, Yogyakarta. The validity testing is done using Single Decision Threshold method. Single Decision Threshold is examined in order to determine the four possible results and two possible mistakes, which are TP (true positive), FP (false positive), FN (false negative), and TN (true negative).

\begin{tabular}{|c|l|l|}
\hline No & \multicolumn{1}{|c|}{ Test Results } & System Testing Results \\
\hline 1 & Short & Short \\
\hline 2 & Short & Short \\
\hline 3 & Very Short & Short \\
\hline 4 & Short & Short \\
\hline 5 & Very Short & Short \\
\hline 6 & Short & Short \\
\hline 7 & Short & Short \\
\hline 8 & Short & Short \\
\hline 9 & Short & Short \\
\hline 10 & Very Short & Very Short \\
\hline 11 & Short & Short \\
\hline 12 & Short & Short \\
\hline 13 & Short & Short \\
\hline 14 & Short & Short \\
\hline 15 & Short & Short \\
\hline 16 & Very Short & Very Short \\
\hline 17 & Short & Short \\
\hline 18 & Short & Short \\
\hline 19 & Short & Short \\
\hline 20 & Very Short & Very Short \\
\hline
\end{tabular}

Table 2. 1 Table result of the system testing

*name of corresponding author 


$$
\begin{aligned}
& \text { Specificity: } \frac{T P}{T P+F N} \times 100 \%=\frac{15}{15+2} \times 100 \%=88,2 \% \\
& \text { Specificity: } \frac{T N}{F P+T N} \times 100 \%=\frac{3}{0+3} \times 100 \%=100 \%
\end{aligned}
$$

\subsubsection{Usability Testing}

Usability Testing is done in order to test the effectiveness, efficiency, and users' satisfaction of the system. There are five criteria to measure the function of the system, namely Learnability (easy to learn), Efficiency (efficient), Memorability (easy to remember), Satisfaction (users' satisfaction), and Errors (preventing the mistakes). (Jeff Rubin, 2008) The testing is done to three respondents, midwife, Community Health Care's nutritionist, and parents. The testing scenario is done by asking the respondents to use the system then give the assessment in the questionnaire based on the questions, which cover the five criteria. The result of the assessment using usability testing based on the five criteria is presented below.

\begin{tabular}{|l|c|c|}
\hline \multicolumn{1}{|c|}{ Criteria } & Total Samples & Average Rating \\
\hline Learnability & 3 & $100 \%$ \\
\hline Efficiency & 3 & $93,30 \%$ \\
\hline Memoriability & 3 & $93,30 \%$ \\
\hline Satisfaction & 3 & $93,30 \%$ \\
\hline Errors & 3 & $80 \%$ \\
\hline
\end{tabular}

Table 4.2. 1 Table result of usability testing

Table 4.2.1 is the result of the the questionnaire assessment, which is being processed using likert scale. It shows the results of the system testing with the details Learnability up to $100 \%$, Efficiency for $93,3 \%$, Memorability up to $93,3 \%$, Satisfaction for $93,3 \%$, and Errors up to $80 \%$.

\section{CONCLUSION}

Based on the analysis, it can be concluded that Stunting is one of the health problems, which can affect the children's growth and development in the long term. Stunting cannot be cured, but the optimization of the children's growth and development can be done based on the management of their nutritional status.

Stunting Management Monitoring System has been tested using usability testing. It works well and meets the needs as the medium for monitoring the maternal and children health as well as providing information related to the management based on the nutritional status with the detail Learnability up to $100 \%$, Efficiency for $93,3 \%$, Memorability for $93,3 \%$, Satisfaction for $93,3 \%$, and Errors for $80 \%$. On testing the validity of determining the children's nutritional status has the sensitivity value up to $88,2 \%$, specificity up to $100 \%$, and system performance for $90 \%$.

\section{REFERENCES}

Afiyan Nur Chafidin, Agung Triayudi, A. (2021). Sistem Pendeteksi Gejala Stunting pada Anak dengan Metode Certainty factor Berbasis Website.

Asweros Umbu Zogara, M. G. P. (2020). Faktor-faktor yang Berhubungan dengan Kejadian Stunting pada Balita. Jurnal Ilmu Kesehatan Masyarakat.

Budiastutik, I., \& Rahfiludin, M. Z. (2019). Faktor Risiko Stunting pada anak di Negara Berkembang. Amerta Nutrition, 3(3), 122. https://doi.org/10.20473/amnt.v3i3.2019.122-129

Chowdhary, K. R. (2020). Fundamentals of artificial intelligence. In Fundamentals of Artificial Intelligence. https://doi.org/10.1007/978-81-322-3972-7

Farid Wajidi, N. N. (2021). Sistem Pakar Diagnosa Stunting Pada Balita Menggunakan Metode Forward Chaining.

*name of corresponding author 
Hendryani, A. (2020). Pengembangan Aplikasi Mobile Health Berbasis Android untuk Monitoring dan Evaluasi Stunting.

Jeff Rubin, D. C. (2008). Handbook of Usability Testing. Wiley Publishing, Inc.

Kementerian Desa Pembangunan Daerah Tertinggal dan Transmigrasi. (2017). Buku saku desa dalam penanganan stunting. Buku Saku Desa Dalam Penanganan Stunting, 2-13.

Kementerian Kesehatan RI. (2018). Pusdatin : buletin stunting. Kementerian Kesehatan RI, 1, 2.

Kementrian Dalam Negeri, Kementerian PPN/Bappenas, T. (2018). Strategi Nasional Percepatan Pencegahan Anak Kerdil (Stunting).

Kesehatan, K., Indonesia, R., Jenderal, D., Gizi, B., Kesehatan, D. A. N., Dan, I. B. U., \& Gizi, D. B. (2011). Gizi Buruk I.

PERATURAN MENTERI KESEHATAN REPUBLIK INDONESIA NOMOR 82 TAHUN 2013 TENTANG SISTEM INFORMASI MANAJEMEN RUMAH SAKIT, 1 (2014).

Susanti, W. I., Widodo, A. P., \& Nugraheni, S. A. (2019). Pengembangan Sistem Informasi Pencatatan dan Pelaporan Status Gizi Balita Stunting di Kelurahan Gajah Mungkur. Jurnal Manajemen Kesehatan Indonesia, 7(1), 67-74. https://doi.org/10.14710/JMKI.7.1.2019.67-74

Thamaria, N. (2017). Penilaian Status Gizi.

World Health Organization. (2014). Global Nutrition Targets 2025: Stunting Policy Brief. 122(2), 74 76,78 . 